\title{
Can we predict dispersal guilds based on the leaf-height-seed scheme in a disjunct cerrado woodland?
}

\author{
Jardim, AVF. and Batalha, MA.* \\ Departamento de Botânica, Universidade Federal de São Carlos - UFSCar, \\ CP 676, CEP 13565-905, São Carlos, SP, Brazil \\ *e-mail: marcobat@uol.com.br \\ Received February 1, 2007 - Accepted March 13, 2007 - Distributed August 31, 2008
}

\begin{abstract}
Although there have been advances in methods for extracting information about dispersal processes, it is still very difficult to measure them. Predicting dispersal groups using single readily-measured traits would facilitate the emergence of instructive comparisons among ecological strategies of plants and offer a path towards improved synthesis across field experiments. The leaf-height-seed scheme consists of three functional traits: specific leaf area, plant canopy height, and seed mass. We tested, applying logistic regression analysis, whether these traits are potential predictors of dispersal guilds in a disjoint cerrado woodland site in southeastern Brazil. According to our results, none of the plant traits studied could predict dispersal guild; this means that abiotically and biotically dispersed species showed similar values of specific leaf area, height, and seed mass. The species of both guilds exhibited sclerophylly, probably a result of the typical soil nutrient deficiency of cerrado, which also may have placed constraints upon plant canopy height regardless of the dispersal mode. In the cerrado, some abiotically dispersed trees might present higher than expected seed mass as support to the investment in high root-to-shoot ratio at the seedling stage. Seeds of birddispersed species are limited in size and mass because of the small size of most frugivorous birds. Since soil nutrient quality might contribute to the similarity between the dispersal guilds regarding the three traits of the scheme, other plant traits (e.g., root depth distribution and nutrient uptake strategy) that detail the former should be considered in future predictive studies.
\end{abstract}

Keywords: savanna, dispersal groups, functional traits, logistic regression, ecological strategy.

\section{Podemos prever guildas de dispersão com base no esquema folha-altura-semente em um cerrado sensu stricto disjunto?}

\begin{abstract}
Resumo
Embora tenham ocorrido avanços nos métodos de aquisição de informações sobre os processos de dispersão, ainda é difícil medi-los. Predizer grupos de dispersão usando atributos simples e práticos facilitaria o aparecimento de comparações instrutivas entre as estratégias ecológicas das plantas e ofereceria um caminho em direção à síntese efetiva de experimentos de campo. O esquema Folha-Altura-Semente consiste em três atributos funcionais: área foliar específica, altura e massa da semente. Testamos, aplicando análise de regressão logística, se esses atributos são potenciais previsores das guildas de dispersão em uma área disjunta de cerrado sensu stricto no Sudeste brasileiro. Segundo os nossos resultados, nenhum dos atributos estudados pôde prever a guilda de dispersão. Isso significa que espécies abiótica e bioticamente dispersas apresentaram valores similares de área foliar específica, altura e massa da semente. As espécies de ambas as guildas exibiram esclerofilia, provavelmente um resultado da deficiência nutricional típica dos solos do cerrado, o que, por sua vez, pode ter limitado à altura das espécies independentemente do seu modo de dispersão. No cerrado, algumas árvores com dispersão abiótica podem apresentar sementes mais pesadas do que o esperado devido ao investimento em elevada razão raiz-caule no estádio de plântula. Sementes de espécies ornitocóricas são limitadas no seu tamanho e massa por causa do reduzido tamanho da maioria das aves frugívoras. Uma vez que a qualidade nutricional do solo do cerrado pode contribuir com a similaridade entre as guildas de dispersão no que diz respeito aos três atributos do esquema, outros atributos (por ex., distribuição da profundidade da raiz e estratégia de captação de nutrientes) que detalhem a primeira devem ser considerados em estudos futuros.
\end{abstract}

Palavras-chave: savana, guildas de dispersão, atributos funcionais, regressão logística, estratégia ecológica. 


\section{Introduction}

Seed dispersal is a multi-step process that links successive generations of plants (Fuentes, 2000), affects the rates of gene flow, and thus influences genetic structure within and among populations (Ouborg et al., 1999). Dispersal spectra vary from place to place (Willson et al., 1990), presumably because the relative merits of different dispersal modes are affected, among other factors, by attributes of the plant in question - e.g., seed size and plant height (Hughes et al., 1994). Although there have been advances in methods for extracting information about dispersal processes (Nathan and Muller-Landau, 2000), it is still very difficult to measure them (Nathan, 2001).

The use of functional traits is intended to understand and predict vegetation dynamics (Keddy, 1992), dealing with easy, inexpensive, and standardized variables (Cornelissen et al., 2003). According to Westoby (1998), plant ecology strategy schemes (PESSs) - the arrangement of species in categories or along spectra according to their ecological attributes - can describe the plant component of communities in terms of a limited number of ecological component types. The same author proposed a PESS for woody species consisting of three axes: 1) specific leaf area (SLA), area per unit dry mass, crucial to leaf longevity, mean residence time of nutrients, and soil nutrient adaptation; 2) height of the plant's canopy at maturity, associated with competitive vigor and tolerance or avoidance of environmental (climatic, nutritional) stress; and 3) seed mass, which influences dispersal and establishment ability. The Leaf-Height-Seed (LHS) PESS has been used to discriminate ecological strategies from endemic plant species to widespread ones in rocky habitats (Lavergne et al., 2003), and to predict differently managed grasslands (Moog et al., 2005).

Since dispersal mode is influenced by other traits (Westoby et al., 1990; Leishman et al., 1995) and the dispersal process is difficult to sample, to predict dispersal groups using single readily-measured traits like the ones considered in the LHS scheme would facilitate the emergence of instructive comparisons among ecological strategies of plants - quantitatively assessed - and offer a path towards improved synthesis across field experiments (Westoby et al., 2002).

In Brazil, the savanna vegetation, called cerrado, occupied originally an area exceeded only by the Amazonian forest (Ratter et al., 1997). Although the continuous core area of the cerrado formation occurs in central Brazil, there are some extensions and disjunct areas in the southern region (Eiten, 1972). The cerrado vegetation presents a wide physiognomic variation that ranges from grasslands to closed woodlands (Coutinho, 1990). In São Paulo state, for example, closed woodlands are the most frequent physiognomy (Durigan et al., 2003).

We may define a dispersal guild as a functional group characterized by a certain dispersal agent of diaspores, with species dispersed by abiotic mechanisms (including anemo- and autochorous species) and species dispersed by biotic agents (zoochorous species; van der Pijl, 1972).

The height of the seed fall is an important factor related to abiotically dispersed species, because the slower the seed fall, the more efficient the dispersal of such species (Roth, 1987; Nathan et al., 2002; Tackenberg, 2003). As long as, in lower vegetation strata of cerrado woodlands with closed canopies, wind velocity is reduced, wind-dispersed species are associated with upper strata (Oliveira and Moreira, 1992). So, in terms of the LHS PESS, we expect, for closed cerrado woodlands, higher values of plant height and lower values of seed mass in species dispersed by abiotic mechanisms when compared to those dispersed by biotic ones.

SLA has a strong association with site irradiance at higher irradiance sites, SLA is lower (Wright et al., 2005). Thus, for species dispersed by abiotic mechanisms, which are predominantly found in the upper strata of cerrado woodlands with closed canopies (Oliveira and Moreira, 1992) and consequently are supposed to face more irradiance, we expect lower values of SLA than for animal-dispersed species.

The aim of this study was to test whether traits of the LHS scheme are potential predictors of dispersal guilds. In other words, we tried to answer the following question: considering the LHS scheme, do the species dispersed by abiotic means present different ecological strategies than species dispersed by animals?

\section{Material and Methods}

We carried out our study in a cerrado site, at Itirapina, São Paulo State, southeastern Brazil (22 ${ }^{\circ} 12^{\prime}-22^{\circ} 13^{\prime}$ S and $\left.47^{\circ} 50^{\prime}-47^{\circ} 51^{\prime} \mathrm{W}\right)$. Following Coutinho (1990), the site is classified as cerrado sensu stricto, which is a woodland according to Sarmiento (1984), and presents a rather closed canopy. The climate is Köppen's (1948) Cwa, that is, macrothermic temperate with rainy summers and not severely dry winters. We gathered data of rainfall and temperature (from January to September 2004) at the Climatological Station of the University of São Paulo (CHREA-EESC-USP), São Carlos, São Paulo State. In the rainy season (October to March), based on data from January to March 2004, the monthly average rainfall is around $213 \mathrm{~mm}$, and the mean temperature ranges from 18 to $30{ }^{\circ} \mathrm{C}$. In the dry season (April to September), monthly average rainfall lies around $55 \mathrm{~mm}$, and the mean temperature ranges from 11 to $26^{\circ} \mathrm{C}$. The soil in the region is classified as sandy soil - Quartzipsamment (Oliveira and Prado, 1984; Embrapa, 1999). The area belongs to the São Paulo State Forestry Institute, is surrounded by Pinus spp. and Eucalyptus spp. plantations, and has been protected from fire for approximately 20 years.

Each month, from May 2004 to April 2005, we surveyed $1005 \times 5 \mathrm{~m}$ quadrats, randomly selected from a 200 quadrat grid. In each survey, we recorded the iden- 
tity and presence of all woody plants with stem diameter at soil level greater than or equal to $3 \mathrm{~cm}$ (SMA, 1997). We identified each individual in field or, when necessary, by collecting samples for subsequent comparison with material at the Federal University of São Carlos herbarium (Hufscar) or identification keys based on vegetative characters (Batalha et al., 1998; Batalha and Mantovani, 1999).

Of all woody species sampled, we selected those with at least ten individuals (Cornelissen et al., 2003) and that fruited during the sampling period. In addition, we collected fruits of three species (Bauhinia rufa Steud., Dalbergia miscolobium Benth., and Didymopanax vinosum March.), which had at least ten individuals in Itirapina but did not fruit there, in a nearby cerrado reserve $\left(21^{\circ} 58^{\prime}-22^{\circ} 00^{\prime} \mathrm{S}\right.$ and $\left.47^{\circ} 51^{\prime}-47^{\circ} 52^{\prime} \mathrm{W}\right)$, São Carlos, Brazil (approximately $25 \mathrm{~km}$ from the other site). In this reserve, we used the walking-and-gathering method with monthly observations, during the sampling period, along trails including two cerrado physiognomies found in the reserve - campo cerrado and cerrado sensu stricto (Coutinho, 1990).

We classified the sampled species according to two dispersal guilds: 1) species dispersed by abiotic mechanisms, which included anemochorous species (with winged seeds, plumes, or other wind-dispersed features) and autochorous species (dispersed entirely by free fall or propelled explosively by a fruit that opens suddenly); and 2) species dispersed by biotic mechanisms, or zoochorous species, with diaspores attached to a fleshy pulp, aril, or other features typically associated with animal dispersal agents (van der Pijl, 1972).

We defined and measured plant height, specific leaf area (SLA), and seed mass following Cornelissen et al.'s (2003) protocol. We measured plant canopy height in ten individuals per species, randomly sampled, using a telescopic stick. From ten individuals per species, randomly sampled, we collected 20 leaves (two leaves from each individual), took digital pictures of each leaf, and measured its area with the ImageJ 1.34 software (Rasband, 2004). After area measurement, we placed each leaf sample in the oven at $80^{\circ} \mathrm{C}$ for 48 hours, and then we weighed the dry mass. The average SLA for each individual plant was one statistical observation. We collected 100 seeds from at least three individuals per species and used an analytical balance to weight the seeds. We took randomly ten seeds per species to do the statistical analyses.

We applied logistic regression analysis (Hosmer and Lemeshow, 1989; Ryan, 1997) to test whether SLA, plant height, and seed mass could predict dispersal guild. First, we divided the total sample randomly into two subsamples, the analysis sample and the validation sample, following a proportionately stratified sampling procedure to make the analysis (Hair et al., 1998). The analysis sample and the validation sample comprised 60 and 40 percent, respectively, of the total sample. For each species considered, we sampled randomly six indi- viduals for the analysis sample and four individuals for the validation sample to keep the same number of individuals of each species. Then, we modeled the relationship between the binary response variable (one $=$ abiotic dispersal guild; zero = biotic dispersal guild) and each of the explanatory variables (univariate analyses). Before conducting the multivariate analysis (multiple logistic regression), we checked whether SLA, plant height, and seed mass were correlated, applying the Spearman correlation test (Sokal and Rohlf, 1994). For the assessment of the significance of the models, we used the likelihood ratio test and the Wald statistic (Hosmer and Lemeshow, 1989; Hair et al., 1998). For the measurement of the goodness of fit of the final model, we intended to use: 1) the "Nalgerke $R^{2 "}$, the only measure of goodness of fit calculated using the analysis data set; 2) the correct classification rate (CCR) with a cutoff value based on the proportion of 1's; 3) the Pearson residuals; 4) the deviance residuals; and 5) the Hosmer and Lemeshow test (Hosmer and Lemeshow, 1989; Neter et al., 1989; Ryan, 1997). We conducted statistical analyses using the Statistica version 6.0 software (StatSoft, 2001).

\section{Results}

We found 11 species that fruited during the sampling period with at least ten individuals, three of which dispersed by abiotic means and eight, by biotic means (Table 1). Thus, the total sample comprised 110 individuals, 30 dispersed by abiotic means and 80 dispersed by biotic means. The analysis sample considered 66 individuals ( $60 \%$ of the total sample), 18 for the abiotic guild and 48 for the biotic guild, and the validation sample dealt with 44 individuals ( $40 \%$ of the total sample), 12 for the abiotic guild and 32 for the biotic guild.

Concerning the univariate analyses, the SLA model was not significant, but the plant height and the seed mass models were significantly related to dispersal guild (Table 2). Building the multivariate model was not possible, because plant height and seed mass variables were correlated $(r=0.36 ; \mathrm{P}=0.003)$, considering the analysis data set. We proceeded the analysis by calculating the several measures of goodness of fit of the significant univariate models (the plant height and the seed mass models).

The $\mathrm{R}^{2}$ values were 0.14 and 0.40 for the plant height and the seed mass models, respectively. The CCR of the plant height model was 70.45 percent, with 50.00 percent of the abiotic dispersal group and 78.12 percent of the biotic dispersal group being correctly classified. For the seed mass model, the CCR was 65.91 percent, with 41.67 percent of the abiotic dispersal group and 75.00 percent of the biotic dispersal group being correctly classified. The Pearson and the deviance tests were significant neither to the plant height model $\left[X^{2}=51.13\right.$ $(0.10<\mathrm{P}<0.25) ; \mathrm{D}=48.89(0.10<\mathrm{P}<0.25)$, respectively] 
Table 1. Dispersal guild (DG; A = species dispersed by abiotic mechanisms, B = species dispersed by biotic mechanisms), specific leaf area (SLA), plant canopy height (H), and seed mass (SM) of cerrado species sampled from May 2004 to April 2005 in Itirapina, southeastern Brazil.

\begin{tabular}{lccccc}
\hline \multicolumn{1}{c}{ Species } & Family & DG & $\begin{array}{c}\text { SLA } \\
\left(\mathbf{m m}^{\mathbf{2}} \mathbf{m g}^{-\mathbf{1}} \mathbf{b}^{\mathbf{b}}\right.\end{array}$ & $\begin{array}{c}\mathbf{H} \\
(\mathbf{m})^{\mathbf{b}}\end{array}$ & $\begin{array}{c}\text { SM } \\
(\mathbf{m g})^{\mathbf{b}}\end{array}$ \\
\hline Anadenanthera falcata (Benth.) Speg. & FAB & A & $8.18(1.17)$ & $6.38(2.45)$ & $33.15(2.92)$ \\
Bauhinia rufa Steud. & FAB & A & $12.28(1.90)$ & $3.29(0.47)$ & $58.65(27.68)$ \\
Dalbergia miscolobium Benth. & FAB & A & $7.63(0.70)$ & $8.49(2.80)$ & $107.15(11.27)$ \\
Didymopanax vinosum March. & API & B & $7.12(0.61)$ & $3.20(0.64)$ & $12.60(1.03)$ \\
Erythroxylum pelleterianum St. Hil. & ERX & B & $20.90(1.65)$ & $2.39(0.65)$ & $7.85(0.87)$ \\
Miconia albicans Triana & MLS & B & $7.88(0.77)$ & $2.43(0.40)$ & $0.27(0.02)$ \\
Miconia rubiginosa (Bonpl.) A.DC. & MLS & B & $6.94(1.38)$ & $4.11(1.65)$ & $2.65(0.30)$ \\
Myrcia lingua Berg. & MRT & B & $8.57(1.39)$ & $3.12(0.93)$ & $28.05(5.47)$ \\
Ocotea pulchella Mart. & LAU & B & $9.09(0.97)$ & $4.18(0.66)$ & $72.90(8.25)$ \\
Rapanea guianensis (Aubl.) Kuntz. & MRS & B & $9.65(1.06)$ & $4.21(0.77)$ & $18.05(1.02)$ \\
Xylopia aromatica (Lam.) Mart. & ANN & B & $11.29(1.18)$ & $4.97(0.79)$ & $41.05(3.23)$ \\
\hline
\end{tabular}

${ }^{a}$ Family names are abbreviated according to Weber (1982); ${ }^{b}$ Median values (and median absolute deviation).

Table 2. Univariate logistic regression models for cerrado species sampled from May 2004 to April 2005 in Itirapina, southeastern Brazil. The univariate models are: specific leaf area model (SLA), plant height model (H), and seed mass model $(\mathrm{SM}) ; \hat{\beta}=$ parameter estimate for the variable of the univariate model (the constants of the univariate models were omitted); $\hat{\mathrm{SE}}=$ estimated standard error of the parameter estimate; $\mathrm{W}=$ univariate Wald statistic $; \mathrm{L}=$ likelihood value for the univariate model; $\mathrm{G}=$ likelihood ratio test statistic. The first row shows the constant only model.

\begin{tabular}{lccccccc}
\hline \multicolumn{1}{c}{ Model } & $\hat{\beta}$ & $\hat{\mathbf{S E}}$ & $\mathbf{W}$ & $\mathbf{P}$ & $\mathbf{L}$ & $\mathbf{G}$ & $\mathbf{P}$ \\
\hline constant & -0.981 & 0.276 & 12.594 & $<0.001$ & -38.673 & - & - \\
SLA & -0.060 & 0.079 & 0.570 & 0.45 & -38.360 & 0.625 & 0.42 \\
H & 0.318 & 0.129 & 6.088 & 0.01 & -35.359 & 6.629 & 0.01 \\
SM & 0.041 & 0.011 & 14.741 & $<0.001$ & -27.857 & 21.632 & $<0.001$ \\
\hline
\end{tabular}

nor to the seed mass model $\left[\mathrm{X}^{2}=44.61(0.25<\mathrm{P}<0.50)\right.$; $\mathrm{D}=41.50(0.25<\mathrm{P}<0.50)$, respectively].

We did not proceed with the Hosmer and Lemeshow test in both models, because none of the frequencies estimated by such models was higher than five and because there were several expected frequencies lower than one (see Hosmer and Lemeshow, 1989). In summary, none of the studied variables could predict dispersal guild.

\section{Discussion}

We observed, during a one-year period, more biotically than abiotically dispersed species fruiting in the woody component of the cerrado, which is expected, since the cerrado woody component is characterized by a higher proportion of zoochorous species, especially in rather closed physiognomies such as the one we studied (Batalha and Martins, 2004). None of the studied variables - SLA, plant height, and seed mass - could predict dispersal guild in the community studied.

Differences in SLA for plants in high-and low-light habitats may represent adaptive adjustments in leaf mor- phology for maximizing light interception in the shade and minimizing water loss in the sun (Larcher, 1995). For cerrado trees, soil water availability per se does not limit their transpiration, but high atmospheric evaporative demand and hydraulic constraints possibly arising from their deep root habit do (Meinzer et al., 1999). Similar adaptative adjustments in SLA of the cerrado woody species studied may be a consequence of their similar canopy heights - abiotically and biotically dispersed species occupying similar stratum in the dense woodland site, which may indicate that there are no differences in their habitats regarding light availability. Similar adjustments in SLA of both dispersal guilds should be modulated, at least in part, by similar light availability, since site to site variation in light availability is the main factor that determines the photosynthetic photon flux density absorbed per unit leaf area by individual plants (Valladares et al., 2002).

Moreover, since plant height is a positive predictor of pathogen attack among cerrado plant species (Marquis et al., 2001), trees with similar canopy heights may intercept the same number of wind-borne spores, which would 
influence homogeneously SLA. Leaf toughness is another trait that should contribute to the non-difference of SLA, since leaves of cerrado species are generally tough or sclerophyllous (Marquis et al., 2001). Sclerophylly in cerrado plants has been related to soil nutrient deficiency, which limits their growth and could lead them to accumulate carbohydrates as mechanical structures, such as cellulose depositions, thick cuticle, and sclerenchyma (Arens, 1958). According to such a postulate, high light levels and lack of water stress would result in an abundance of assimilated $\mathrm{CO}_{2}$, consumed in the production of structural elements in the leaves because of low availability of nutrients for growth.

The two cerrado dispersal guilds did not differ in their plant canopy heights either. The closed canopy of the studied site suggests an increased competition for light, which would favour increased investment in height growth (Givnish, 1982). Indeed, along the cerrado physiognomic gradient, from pure grassland to woodland with a closed canopy, mean and maximum tree height increase (Castro and Kauffman, 1998). In the community we studied, species from distinct dispersal guilds seem to behave similarly in regard to the running for light in terms of height.

Species with abiotic dispersal usually have smaller seeds than species dispersed by animals (Moles et al., 2005). However, we found similar seed mass irrespective of the dispersal group, a result influenced by the higher than expected seed mass values of the species dispersed by abiotic mechanisms and by the lower than expected seed mass values of the zoochorous group. Similar to Hughes et al. (1994), who analyzed temperate floras, most seeds in a tropical community like the one we studied are between 0.1 and $100 \mathrm{mg}$, a range within which all of the dispersal modes are feasible. One may suggest that the non-difference found between the dispersal guilds regarding the seed mass is a consequence of phylogenetic constraint, given that the three species comprising the abiotically dispersed guild are of the same family, that is, Fabaceae. Although seed mass is related to phylogeny, it could vary considerably within taxonomic groups, and there are no hard constraints to the evolution of seed masses much higher or lower than group means; these outliers contradict intrinsic phylogenetic constraint (Lord et al., 1995).

In the cerrado, some abiotically dispersed trees might present higher than expected seed mass to invest in high root-to-shoot ratio of biomass allocation at the seedling stage (Sassaki and Felippe, 1999; Moreira and Klink, 2000). The high root-to-shoot ratio seems to be an adaptation to withstand the dry season during the first stages of life (Rizzini, 1965), to resprout from underground organs after fire at the adult stage (Franco, 1998), and to withstand the low soil nutrient content (Lilienfein et al., 2001).

All zoochorous species that fruited in the study period were bird-dispersed (Gottsberger and SilberbauerGottsberger, 1983; Silva-Júnior, 2005), whose seeds are not typically large (Howe and Westley, 1991; Kay, 1992). The ornithochorous species accurately represents the zoochorous guild, since birds form the most important group of frugivores (Kay, 1992). In another disjunct cerrado site, Gottsberger and Silberbauer-Gottsberger (1983) observed that, among trees, most species were dispersed by birds. Plant species with zoochorous dispersal may target birds more often than mammals and other animals because of the higher species richness of the former (Willson et al., 1989).

The small size of most frugivorous birds places an ecologically important limit on the size and mass of birddispersed seeds (Kay, 1992). Not only are birds sensitive to the amount of ballast that they carry and tend to prefer trees with small fruits, but also trees with high ratios of edible aril to indigestible seed show the greatest removal success, especially during periods of fruit scarcity (Howe and Westley, 1991). Additionally, in the cerrado, some plants associated with vertebrate dispersers, especially birds, may have their diaspores collected by ants (Gottsberger and Silberbauer-Gottsberger, 1983; Leal and Oliveira, 1998). Their seeds may benefit from being dropped by ants in safe spots beneath the leaf litter, where more appropriate microconditions, such as moisture, temperature, and nutrients, favor seed germination (Harper, 1977; Horvitz, 1981). Pulp and aril removal from fruits of some bird-dispersed species of cerrado results in increased germination success for these species, probably because it reduces fungal attack on them (Leal and Oliveira, 1998).

Our study indicated that the dispersal groups sampled in a southern cerrado woodland cannot be predicted by the traits of the LHS scheme. In other words, the species dispersed by abiotic means did not present different ecological strategies from species dispersed by animals, considering the LHS scheme. As suggested by Westoby et al. (2002), the number of traits as predictors of ecological behavior does not need to stop at three. Because soil nutrient quality might contribute to the similarity between the dispersal guilds regarding the three traits of the scheme - leading to sclerophyllous leaves, plants similarly constrained in height, and seeds abiotically dispersed with a more than expected mass - , other plant traits that detail soil nutrient quality (e.g., root depth distribution and nutrient uptake strategy) should be taken into account in future predictive studies. Also, the importance of bird-dispersed species in the zoochorous group of cerrado points out that a more detailed classification of the biotically dispersed one would help to clarify the relationship between dispersers and plant traits, especially seed mass.

Although our predictions were clear and based on a reasonable number of observations (Hair et al., 1998), our study considered a small number of species. Therefore, forthcoming studies on the relationship of plant traits and dispersal guilds with a larger number of species would reach more accurate predictions of the ecological strategies of groups with particular ecological affinities. 
Acknowledgements - We are grateful to Capes for the scholarship granted to the first author; to the São Paulo State Forestry Institute for research permission; to the Itirapina Experimental Station staff for logistical assistance; to S. C. J. G. A. Perez and M. I. S. Lima for logistical support and valuable comments on the manuscript; to C. H. B. A. Prado for valuable comments on the manuscript; to F. R. Martins, J. M. Polo, and D. M. Silva Matos for logistical support; to M. Arduin for advice about image processing softwares; to "Sampling - Consultoria Estatística e Pesquisa de Mercado" for statistical consulting; to T. B. de Almeida, G. H. de Carvalho, M. V. Cianciaruso, S. C. Emerique, P. M. Lo Sardo, M. Maia, F. Q. Martins, K. G. Massi, D. M. da Silva, I. A. da Silva, T. Siqueira, and M. W. Valenti for friendship and help in the field.

\section{References}

ARENS, K., 1958. Considerações sobre as causas do xeromorfismo foliar. Bolm. Fac. Ciênc. Let. Univ. S. Paulo, vol. 224 , no. 15 , p. $25-26$.

BATALHA, MA. and MANTOVANI, W., 1999. Chaves de identificação das espécies vegetais vasculares do cerrado baseada em caracteres vegetativos para a ARIE Cerrado Péde-Gigante, Santa Rita do Passa Quatro, SP. Rev. Inst. Flor., vol. 11 , no. 1 , p. 137-158.

BATALHA, MA. and MARTINS, FR., 2004. Reproductive phenology of the cerrado plant community in Emas National Park (central Brazil). Aust. J. Bot., vol. 52, no. 2, p. 149-161.

BATALHA, MA., ARAGAKI, S. and MANTOVANI, W., 1998. Chave de identificação das espécies vasculares do cerrado em Emas (Pirassununga, SP) baseada em caracteres vegetativos. Bolm. Bot. Univ. S. Paulo, vol. 17, no. 1, p. 85-108.

BUSTAMANTE, MMC., MARTINELLI, MA., SILVA, DA., CAMARGO, PB., KLINK, CA., DOMINGUES, TF. and SANTOS, RV., 2004. N natural abundance in woody plants and soils of Central Brazilian savannas (cerrado). Ecol. Appl., vol. 14, p. S200-S213.

CASTRO, EA. and KAUFFMAN, JB., 1998. Ecosystem structure in the Brazilian Cerrado: a vegetation gradient of aboveground biomass, root mass and consumption by fire. J. Trop. Ecol., vol. 14, no. 4, p. 263-283.

CORNELISSEN, JHC., LAVOREL, S., GARNIER, E., DÍAZ, S., BUCHMANN, N., GURVICH, DE., REICH, PB., TERSTEEGE, H., MORGAN, HD., VAN DER HEIJDEN, MGA., PAUSAS, JG. and POORTER, H., 2003. A handbook of protocols for standardised and easy measurement of plant functional traits worldwide. Aust. J. Bot., vol. 51, no. 4, p. 335-380.

COUTINHO, LM., 1990. Fire in the ecology of the Brazilian Cerrado. In Goldammer, JG. (Ed.). Fire in the tropical biota: ecosystem processes and global challenges. Berlin: Springer. p. $82-105$.

DURIGAN, G., SIQUEIRA, MF., FRANCO, GADC., BRIDGEWATER, S. and RATTER, JA., 2003. The vegetation of priority areas for cerrado conservation in São Paulo State, Brazil. Edinburgh J. Bot., vol. 60, no. 2, p. 217-241.

EITEN, G., 1972. The cerrado vegetation of Brazil. Bot. Rev., vol. 38 , no. 2 , p. $201-341$.

EMBRAPA. EMPRESA BRASILEIRA DE PESQUISA AGROPECUÁRIA, 1999. Sistema brasileiro de classificação de solos. Brasília: EMBRAPA-SPI.
FRANCO, AC., 1998. Seasonal patterns of gas exchange, water relations and growth of Roupala montana, an evergreen savanna species. Plant Ecol., vol. 136, no. 1, p. 69-76.

FUENTES, M., 2000. Frugivory, seed dispersal and plant community ecology. TREE, vol. 15 , no. 12 , p. 487-488.

GIVNISH, TJ., 1982. On the adaptive significance of leaf height in forest herbs. Am. Nat., vol. 120, no. 3, p. 353-381.

GOTTSBERGER, G. and SILBERBAUER GOTTSBERGER, I., 1983. Dispersal and distribution in the cerrado vegetation of Brazil. Sonderbd. Naturwiss. Ver. Hamburg, vol. 7, p. 315-352.

HAIR JR, JF., ANDERSON, RE., TATHAM, RL. and BLACK, WC., 1998. Multivariate data analysis. Upper Saddle River: Prentice-Hall. 730 p.

HARPER, JL., 1977. Population biology of plants. London: Academic Press. 892 p.

HORVITZ, CC., 1981. Analysis of how ant behaviors affect germination in a tropical myrmechocore Calathea microcephala (P. and E.) Koernicke (Marantaceae): microsite selection and aril removal by Neotropical ants, Odontomachus, Pachycondyla, and Solenopsis (Formicidae). Oecologia, vol. 51, no. 1, p. 47-52.

HOSMER, DW. and LEMESHOW, S., 1989. Applied logistic regression. New York: John Wiley \& Sons. 307 p.

HOWE, HF. and WESTLEY, LC., 1991. Ecology of pollination and seed dispersal. In Crawley, MJ. (Ed.). Plant ecology. Oxford: Blackwell Scientific Publications. p. 262-283

HUGHES, L., DUNLOP, M., FRENCH, K., LEISHMAN, MR., RICE, B., RODGERSON, L. and WESTOBY, M., 1994. Predicting dispersal spectra: a minimal set of hypotheses based on plant attributes. J. Ecol., vol. 82, no. 4, p. 933-950.

KAY, QON., 1992. Edible fruits in a cool climate: the evolution and ecology of endozoochory in the European flora. In Marshall, C. and Grace, J. (Eds.). Fruit and seed production: aspects of development, environmental physiology and ecology. Cambridge: Cambridge University Press. p. 217-250

KEDDY, PA., 1992. A pragmatic approach to functional ecology. Funct. Ecol., vol. 6, no. 6, p. 621-626.

KÖPPEN, W., 1948. Climatología. Mexico City: Fondo de Cultura Económica. 479 p.

LARCHER, W., 1995. Physiological plant ecology. New York: Springer. $506 \mathrm{p}$.

LAVERGNE, S., GARNIER, E. and DEBUSSCHE, M., 2003. Do rock endemic and widespread plant species differ under the Leaf-Height-Seed plant ecology strategy scheme? Ecol. Lett., vol. 6 , no. 5, p. 398-404.

LEAL, IR. and OLIVEIRA, PS., 1998. Interactions between fungus-growing ants (Attini), fruits and seeds in cerrado vegetation in Southeast Brazil. Biotropica, vol. 30, no. 2, p. $170-178$.

LEISHMAN, MR., WESTOBY, M. and JURADO, E., 1995. Correlates of seed size variation: a comparison among five temperate floras. J. Ecol., vol. 83, no. 3, p. 517-529.

LILIENFEIN, J., WILCKE, W., ZIMMERMANN, R., GERSTBERGER, P., ARAÚJO, GM. and ZECH, W., 2001. Nutrient storage in soil and biomass of native Brazilian Cerrado. J. Plant Nutr. Soil Sci., vol. 164, no. 5, p. 487-495. 
LORD, J., WESTOBY, M. and LEISHMAN, M., 1995. Seed size and phylogeny in six temperate floras: constraints, niche conservatism and adaptation. Am. Nat., vol. 146, no. 3, p. 349-364.

MARQUIS, RJ., DINIZ, IR. and MORAIS, HC., 2001. Patterns and correlates of interspecific variation in foliar insect herbivory and pathogen attack in Brazilian cerrado. J. Trop. Ecol., vol. 17, no. 1, p. 127-148.

MEINZER, FC., GOLDSTEIN, G., FRANCO, AC., BUSTAMANTE, M., IGLER, E., JACKSON, P., CALDAS, L. and RUNDEL, PW., 1999. Atmospheric and hydraulic limitations on transpiration in Brazilian Cerrado woody species. Funct. Ecol., vol. 13, no. 2, p. 273-282.

MOLES, AT., ACKERLY, DD., WEBB, CO., TWEDDLE, JC., DICKIE, JB., PITMAN, AJ. and WESTOBY, M., 2005. Factors that shape seed mass evolution. Proc. Nat. Acad. Sci., vol. 102, no. 30 , p. $10540-10544$.

MOOG, D., KAHMEN, S. and POSCHLOD, P., 2005. Application of CSR- and LHS-strategies for the distinction of differently managed grasslands. Basic Appl. Ecol., vol. 6, no. 2, p. 133-143.

MOREIRA, A. and KLINK, CA., 2000. Biomass allocation and growth of tree seedlings from two contrasting Brazilian savannas. Ecotropicos, vol. 13, no. 1, p. 43-51.

NATHAN, R., 2001. The challenges of studying dispersal. TREE, vol. 16, no. 9, p. 481-483.

NATHAN, R., KATUL, GG., HORN, HS., THOMAS, SM., OREN, R., AVISSAR, R., PACALA, SW. and LEVIN, SA., 2002. Mechanisms of long-distance dispersal of seeds by wind. Nature, vol. 418, no. 6896, p. 409-413.

NATHAN, R. and MULLER LANDAU, HC., 2000. Spatial patterns of seed dispersal, their determinants and consequences for recruitment. TREE, vol. 15, no. 7, p. 278-285.

NETER, J., WASSERMAN, W. and KUTNER, MH., 1989. Applied linear regression models. Homewood: Irwin. 688 p.

OLIVEIRA, JB. and PRADO, H., 1984. Levantamento pedológico semidetalhado do estado de São Paulo: quadrícula de São Carlos II. Campinas: Embrapa/SAA/IAC. (Boletim Técnico 98)

OLIVEIRA, PEAM. and MOREIRA, AG., 1992. Anemocoria em espécies de cerrado e mata de galeria de Brasília, DF. Rev. Bras. Bot., vol. 15, no. 2, p. 163-174.

OUBORG, NJ., PIQUOT, Y. and VAN GROENENDAEL, JM., 1999. Population genetics, molecular markers and the study of dispersal in plants. J. Ecol., vol. 87, no. 4, p. 551-568.

RASBAND, W., 2004. ImageJ: Image processing and analysis in Java. Version 1.34s. [06 08, 2006]. Available from: http://rsb. info.nih.gov/ij.

RATTER, JA., RIBEIRO, JF. and BRIDGEWATER, S., 1997. The Brazilian Cerrado vegetation and threats to its biodiversity. Ann. Bot., vol. 80, no. 3, p. 223-230.

RIZZINI, CT., 1965. Experimental studies on seedlings development. Ann. Mo. Bot. Gard., vol. 52, no. 3, p. 410-426.
ROTH, I., 1987. Stratification of a tropical forest as seen in dispersal types. Dordrecht: Dr. W. Junk. 324 p.

RYAN, TP., 1997. Modern regression methods. New York: John Wiley \& Sons. 515 p.

SECRETARIA DO MEIO AMBIENTE, 1997. Cerrado: bases para conservação e uso sustentável das áreas de cerrado do estado de São Paulo. São Paulo: SMA. 184 p.

SARMIENTO, G., 1984. The ecology of neotropical savannas. Cambridge: Harvard University. 235 p.

SASSAKI, RM. and FELIPPE, GM., 1999. Single-seeded fruits and seedling establishment in Dalbergia miscolobium Benth. (Papilionaceae). Biotropica, vol. 31, no. 4, p. 591-597.

SILVA JÚNIOR, MC., 2005. 100 árvores do cerrado: guia de campo. Rede de sementes do cerrado. Brasília: Rede de Sementes do Cerrado . 278 p.

SOKAL, RR. and ROHLF, FJ., 1994. Biometry. New York: W. H. Freeman. 880 p.

STATSOFT, INC., 2001. Statistica (data analysis software system). Version 6. [06 08, 2006]. Available from: http://www. statsoft.com.

TACKENBERG, O., 2003. Modeling long-distance dispersal of plant diaspores by wind. Ecol. Monogr., vol. 73, no. 2, p. 173-189.

VALLADARES, F., SKILLMAN, JB. and PEARCY, RW., 2002. Convergence in light capture efficiencies among tropical forest understory plants with contrasting crown architectures: a case of morphological compensation. Am. J. Bot., vol. 89, no. 8, p. $1275-1284$.

VAN DER PIJL, L., 1972. Principles of dispersal in higher plants. Berlin: Springer. $162 \mathrm{p}$.

WEBER, WA., 1982. Mnemonic three-letter acronyms for the families of vascular plants: a device for more effective herbarium curation. Taxon, vol. 31, p. 74-88.

WESTOBY, M., 1998. A leaf-height-seed (LHS) plant ecology strategy scheme. Plant Soil, vol. 199, no. 2, p. 213-227.

WESTOBY, M., RICE, B., HOWELL, J., 1990. Seed size and plant growth form as factors in dispersal spectra. Ecology, vol. 71 , no. 4 , p. $1307-1315$.

WESTOBY, M., FALSTER, DS., MOLES, AT., VESK, PA. and WRIGHT, IJ., 2002. Plant ecological strategies: some leading dimensions of variation between species. Annu. Rev. Ecol. Syst., vol. 33, p. 125-159.

WILLSON, MF., IRVINE, AK. and WALSH, NG., 1989. Vertebrate dispersal syndromes in some Australian and New Zealand plant communities, with geographic comparisons. Biotropica, vol. 21, no. 2, p. 133-147.

WILLSON, MF., RICE, BL. and WESTOBY, M., 1990. Seed dispersal spectra: a comparison of temperate plant communities. J. Veg. Sci., vol. 1, no. 4, p. 547-562.

WRIGHT, IA., REICH, PB., CORNELISSEN, JHC., FALSTER, DS., GROOM, PK., HIKOSAKA, K., LEE, W., LUSK, CH., NIINEMETS, U., OLEKSYN, J., OSADA, N., POORTER, H., WARTON, DI. and WESTOBY, M., 2005. Modulation of leaf economic traits and trait relationships by climate. Global Ecol. Biogeogr., vol. 14, no. 5, p. 411-421. 